\title{
The Effect of Sugar and Agar-agar Concentration on Nypa Fruit Slice Jam
}

\author{
S Surhaini*, M Mursyid* \\ * Technology of Agricultural Product Department, University of Jambi, Jambi \\ E-mail: surhaini@unja.ac.id
}

\begin{abstract}
Nypa fruticans or known as nypa produces considerable amount of fruit with high content of carbohydrate. The mesocarp of the mature fruit is a potential source of energy but underutilised. This research was conducted to study the production of nypa slice jam by focussing on the effect of sugar and agar-agar concentration on the physical, chemical and sensory properties of nypa slice jam. Sugar and agar-agar concentration affect rendemen, crude fibre content, total soluble solid, water content, colour, texture, taste, flavour and overal acceptance of slice jam from nypa fruit.
\end{abstract}

Keywords— Nypa fruticans; slice jam; young fruit

\section{INTRODUCTION}

Nypa fruticans is classified as palm. It is a native plant of Asia. According to report from FAO [1], native distribution and habitat of nypa are the South and Southeast Asia, in tropical rain forest at brackish water swamps of tidal rivers. Furthermore, FAO has declared nypa fruticans as nonthreatened palm in South East Asia hence available in considerable amount to be utilised. Nypa thrives in mangroves areas in Jambi Province but underutilised. Several parts of nypa tree have been utilised such as leaves for thatching or roofing and nypa sap for making sugar. The other parts such as the the frond and the fruits have not been utilised yet. The fruit itself consist of husk, shell and the mesocarp. While the husk and shell are promising biomass resource for biofuel and chemical [2], the mesocarp is promising to be exploited as food [3].

Mesocarp of nypa palm contains different amount of carbohydrate, protein, fat and ash depend on the growth location and the maturity of the fruit [4]. Young fruit contains high amount of water (up to $80 \%$ ) and this decreases as maturity of fruit increases. The mature fruit contains considerable amount of carbohydrate $(51.89 \%)$ and very low fat content $(0.48 \%$ to $1.16 \%)$ and low protein content $(0.7 \%$ to $2.4 \%$ ). The chemical composition of nypa mesocarp offers the potential of nypa mesocarp to be processed into flour. The flour of nypa mesocarp has previosly been used for extender in board processing [5]. Nypa flour has also been used for human consumption [6], in which it is used for biscuits. The biscuit was produced using 37.5\% nypa flour and $62.5 \%$ wheat flour was compared well in nutritive value with $100 \%$ wheat biscuit. This research was conducted to study the production of slice jam from mesocarp of young nypa fruit obtained in mangrove area in Jambi Province. The study was focussed on the effect of sugar and agar-agar concentration on the chemical and sensory properties of slice jam.

\section{MATERIAL AND METHODS}

\section{A. Material}

Nypa fruits were obtained from Tungkal Ilir District, West Tanjung Jabung, Jambi Province. The fruits were harvested unripe which can be described to have dark brown skin colour on top of fruit, light brown skin colour on the bottom of fruit and the endosperm has not completely filled in (Fig. 1). Sugar, citric acid, agar-agar and margarine were purchased from local store. Natrium metabisulfit, $\mathrm{H}_{2} \mathrm{SO}_{4}, \mathrm{NaOH}$, $\mathrm{H}_{2} \mathrm{BO}_{3}$, and $\mathrm{HCl}$ were Sigma grade.

\section{B. Methods}

The research was undergone in 2 steps. First step was done to obtain a correct amount of nypa pulp which was done by trial and error. This resulted of slice jam formulation was $65 \%$ nypa pulp, 25-45\% sugar, $2.5-3.5 \%$ agar-agar, $0.5 \%$ citric acid, and 5\% margarine. The percentage was calculate from the total of batter (200 gram). Nypa pulp was made by homogenising 250 gram nypa endosperm and $70 \mathrm{ml}$ of water using commercial blender.

Second step was carried out to produce slice jam using completely randomised block design with two factors (concentration of sugar and agar-agar) and 3 repitition.

Nypa slice jam was made by homogenising nypa pulp, agar, sugar and margarine. The batter was heated up to $95^{\circ} \mathrm{C}$ for 5 minutes. Citric acid was added and the batter was further mixed.

\section{RESUlt AND Discussion}

Please take note of the following items when proofreading spelling and grammar:

\section{A. Rendemen}

Sugar and agar-agar concentration affected rendemen of slice jam $(\mathrm{p} \leq 0.010)$. There was interaction of sugar and agaragar concentration on the rendemen of slice jam. Rendemen 
of slice jam made by using 9 combination of sugar and agaragar concentration is presented in Table 1.

TABLE I

RENDEMEN FOR SLICE JAM

\begin{tabular}{lccc}
\hline Sugar & \multicolumn{4}{c}{ Agar Concentration (\%) } \\
\cline { 2 - 4 } Concentration (\%) & $\mathbf{2 . 5}$ & $\mathbf{3 . 0}$ & $\mathbf{3 . 5}$ \\
\hline 25 & $67.90 \mathrm{~B}$ & $74.29 \mathrm{~B}$ & $81.58 \mathrm{~A}$ \\
& $\mathrm{c}$ & $\mathrm{b}$ & $\mathrm{a}$ \\
\hline 35 & $73.75 \mathrm{~A}$ & $78.87 \mathrm{~A}$ & $80.40 \mathrm{~B}$ \\
& $\mathrm{c}$ & $\mathrm{b}$ & $\mathrm{a}$ \\
\hline 45 & $73.26 \mathrm{~A}$ & $78.61 \mathrm{~A}$ & $80.56 \mathrm{~B}$ \\
& $\mathrm{c}$ & $\mathrm{b}$ & $\mathrm{a}$ \\
\hline
\end{tabular}

\section{B. Physical Properties}

Sugar and agar-agar concentration affected crude fibre content, total soluble solid and water content of slice jam. There was no interaction of sugar and agar-agar concentration on the crude fibre content of slice jam but there was interaction of sugar and agar-agar concentration on the total soluble solid and water content of slice jam. Crude fibre content, total soluble solid and water content of slice jam made by using 9 combination of sugar and agar-agar concentration is presented in Table 2-4.

TABLE II

Crude Fibre Content of SLice Jam

\begin{tabular}{lc}
\hline $\begin{array}{l}\text { Sugar } \\
\text { Concentration (\%) }\end{array}$ & $\begin{array}{c}\text { Average } \\
(\%)\end{array}$ \\
\hline 25 & $0.21 \mathrm{a}$ \\
\hline 35 & $0.22 \mathrm{a}$ \\
\hline 45 & $0.23 \mathrm{ab}$ \\
\hline $\begin{array}{l}\text { Agar Concentration } \\
(\%)\end{array}$ & $\begin{array}{c}\text { Average } \\
(\%)\end{array}$ \\
\hline 2.5 & $0.20 \mathrm{a}$ \\
\hline 3.0 & $0.22 \mathrm{ab}$ \\
\hline 3.5 & $0.24 \mathrm{bc}$ \\
\hline
\end{tabular}

TABLE III

Total Soluble Solid of Slice JaM

\begin{tabular}{lccc}
\hline Sugar & \multicolumn{3}{c}{ Agar Concentration (\%) } \\
\cline { 2 - 4 } Concentration (\%) & $\mathbf{2 . 5}$ & $\mathbf{3 . 0}$ & $\mathbf{3 . 5}$ \\
\hline 25 & $60.67 \mathrm{C}$ & $58.33 \mathrm{C}$ & $54.00 \mathrm{C}$ \\
& $\mathrm{a}$ & $\mathrm{ab}$ & $\mathrm{b}$ \\
\hline 35 & $62.67 \mathrm{~B}$ & $62.00 \mathrm{~B}$ & $61.00 \mathrm{~B}$ \\
& $\mathrm{a}$ & $\mathrm{a}$ & $\mathrm{b}$ \\
\hline 45 & $70.33 \mathrm{~A}$ & $67.00 \mathrm{~A}$ & $66.00 \mathrm{~A}$ \\
& $\mathrm{a}$ & $\mathrm{b}$ & $\mathrm{b}$ \\
\hline
\end{tabular}

TABLE IV

WATER CONTENT OF SLICE JAM

\begin{tabular}{lccc}
\hline Sugar & \multicolumn{3}{c}{ Agar Concentration (\%) } \\
\cline { 2 - 4 } Concentration (\%) & $\mathbf{2 . 5}$ & $\mathbf{3 . 0}$ & $\mathbf{3 . 5}$ \\
\hline 25 & $45.27 \mathrm{~A}$ & $46.29 \mathrm{~A}$ & $48.02 \mathrm{~A}$ \\
& $\mathrm{~b}$ & $\mathrm{Ab}$ & $\mathrm{a}$ \\
\hline 35 & $33.55 \mathrm{~B}$ & $42.38 \mathrm{~B}$ & $42.53 \mathrm{~B}$ \\
& $\mathrm{~b}$ & $\mathrm{a}$ & $\mathrm{a}$ \\
\hline 45 & $33.49 \mathrm{~B}$ & $34.44 \mathrm{C}$ & $37.82 \mathrm{C}$ \\
& $\mathrm{b}$ & $\mathrm{b}$ & $\mathrm{a}$ \\
\hline
\end{tabular}

\section{Sensory Properties}

Sugar and agar-agar concentration affected all parameters in sensory properties as shown in Table 5. The higher the sugar concentration tended to increase all parameters of sensory properties except for taste and flavour of slice jam. However there wasn't any tendencies in increasing the concentration of agar-agar. Concentration of sugar 35\% and agar-agar $3 \%$ produced the best slice jam with brownish yellow, chewy, sweet and good overal acceptance.

TABLE V

SENSORY PROPERTIES OF SLICE JAM

\begin{tabular}{ccccccc}
\hline [sugar]\% & [agar] $\%$ & colour & Texture & Taste & Flavour & $\begin{array}{c}\text { Overal } \\
\text { Acceptance }\end{array}$ \\
\hline 25 & 2.5 & $3.40 \mathrm{bcd}$ & $3.40 \mathrm{bcd}$ & $3.80 \mathrm{a}$ & $3.80 \mathrm{a}$ & $3.00 \mathrm{~d}$ \\
25 & 3.0 & $3.00 \mathrm{de}$ & $3.00 \mathrm{de}$ & $3.85 \mathrm{a}$ & $3.85 \mathrm{a}$ & $3.30 \mathrm{~cd}$ \\
25 & 3.5 & $2.80 \mathrm{e}$ & $2.80 \mathrm{e}$ & $3.70 \mathrm{a}$ & $4.00 \mathrm{a}$ & $2.20 \mathrm{f}$ \\
35 & 2.5 & $3.25 \mathrm{bc}$ & $3.25 \mathrm{bc}$ & $3.90 \mathrm{a}$ & $3.70 \mathrm{a}$ & $3.75 \mathrm{ab}$ \\
35 & 3.0 & $3.50 \mathrm{abc}$ & $3.50 \mathrm{abc}$ & $3.75 \mathrm{a}$ & $3.35 \mathrm{ab}$ & $4.05 \mathrm{a}$ \\
35 & 3.5 & $3.10 \mathrm{cde}$ & $3.10 \mathrm{cde}$ & $3.50 \mathrm{a}$ & $2.95 \mathrm{c}$ & $2.60 \mathrm{~g}$ \\
45 & 2.5 & $3.95 \mathrm{a}$ & $3.95 \mathrm{a}$ & $2.95 \mathrm{~b}$ & $3.65 \mathrm{ab}$ & $3.40 \mathrm{bc}$ \\
45 & 3.0 & $3.80 \mathrm{ab}$ & $3.80 \mathrm{ab}$ & $2.30 \mathrm{c}$ & $2.30 \mathrm{~d}$ & $3.65 \mathrm{bc}$ \\
45 & 3.5 & $3.55 \mathrm{abc}$ & $3.55 \mathrm{abc}$ & $2.20 \mathrm{c}$ & $2.20 \mathrm{~d}$ & $2.25 \mathrm{ef}$ \\
\hline
\end{tabular}




\section{CONCLUSION}

Sugar and agar-agar concentration affect rendemen, crude fibre content, total soluble solid, water content, colour, texture, taste, flavour and overal acceptance of slice jam from nypa fruit.

\section{REFERENCES}

[1] Food Agricultural Organisation of United Nations, Non wood forest product 10 tropical palms. (FAO, Rome, 1998), Available at: http://www.fao.org/docrep/ X0451E/x0451e00.HTM; [accessed 04.01.17].

[2] P Tamunaidu and S Saka, Chemical Characterization of Various Parts of Nipa Palm (Nypa fruticans). Industrial Crops and Products 34, 14231428 (2011).

[3] N.M. Heriyanto, E. Subiandono, E. Karlina. Potensi dan Sebaran Nipah (Nypa fruticans (thunb.) wurmb) Sebagai Sumberdaya Pangan (Potency and Distribution of Nypa Palm (Nypa fruticans (thunb.) wurmb) as a Food Resource. Jurnal Penelitian Hutan dan Konservasi Alam 8, 327 335 (2011).

[4] Ulyarti, D Renate, Surhaini, D W Sari. Kajian Sifat Fisikokimiawi Daging Buah Nipah (Nypa fruticans) dan Pemanfaatannya sebagai Bahan Pangan. Laporan Penelitian, Universitas Jambi, 2016.

[5] Sari NM, Rosidah, Rahman MY. Penggunaan tepung buah nipah (Nypa frutican wurmb) sebagai ekstender pada perekat urea formaldehid untuk papan partikel. Jurnal ilmu kehutanan 1, 48-54 (2008).

[6] U. D. Akpabio, U. C. Essien, O. U. Eka, Chemical Composition of The Kernel of Nypa Fruticans (NYPA PALM) and Its Application In Confectionery Preparation, Global Journal Of Pure And Applied Sciences $\quad$ (abstract), 4, 
